\title{
Kazakhstan's EU policies: a critical review of underlying motives and enabling factors
}

Artem Patalakh(1)

Correspondence:

artem.patalakh@unimi.it

University of Milan, Graduate School

of Social and Political Sciences, via

Pace 10, 20122 Milan, MI, Italy

\begin{abstract}
The article delves into Kazakhstan's policies vis-à-vis the European Union, focusing on their driving motives and enabling conditions. Drawing upon published papers and, to a lesser degree, primary sources, the author argues that friendship with the EU largely serves the Kazakhstani elite as means of economic modernisation as well regime legitimation, perfectly fitting Kazakhstan's dominant domestic discourse which portrays the country as Eurasian and its foreign policy-as multi-vector. The study also shows that Astana's partnership with Brussels is to a large degree possible because the EU holds a simultaneous positive attitude to such partnership regardless Kazakhstan's authoritarian regime. According to the article, such reflects the great instrumental value collaboration with Astana gives Brussels, the EU's general inactivity on democracy promotion in Central Asia and Kazakhstan's looking more pro-European and economically/politically advanced against the background of its post-Soviet and Central Asian autocratic fellows. The paper concludes by reflecting on the configuration of pragmatism and identity in Astana's approach to the EU and discussing the peculiarities of the bloc's power over Kazakhstan.
\end{abstract}

Keywords: Autocracy, Democracy promotion, European Union, Foreign policy, Instrumentality, Kazakhstan, Power, Pragmatism, Russia

\section{Introduction}

In the post-Soviet space, and especially in the Central Asian region, the EU's relations with Kazakhstan stand out. To cite a few facts, Kazakhstan is the country where the bloc in 1993 opened its first-which until 2010 was its only-delegation in Central Asia. Moreover, Kazakhstan is the sole Central Asian state that participates in the Bologna Process and has a second generation agreement with the bloc. ${ }^{1}$ Furthermore, Kazakhstan is the region's only state for which the EU is the main source of FDI and the largest trade partner, accounting for more than a third of its foreign trade and over a half of its FDIs (EU External Action, 2017).

To some, the topic of the Kazakhstani policies toward the EU may appear unoriginal, since it has attracted some scholarly attention in recent years. Yet, this paper is peculiar in its focus and scope. While other studies approach Astana-Brussels relations from either a chronological (e.g. Anceschi, 2014; Kurmanguzhin, 2016) or a law perspective (e.g. Kembayev, 2016) or focus on one single dimension of Kazakhstan-EU ties (e.g. Bossuyt and Kubicek, 2015; Collins and Bekenova, 2017), this article concentrates on driving motives behind Kazakhstan's EU policies as well as factors attendant on their

(C) The Author(s). 2018 Open Access This article is distributed under the terms of the Creative Commons Attribution 4.0 International License (http://creativecommons.org/licenses/by/4.0/), which permits unrestricted use, distribution, and reproduction in any medium, provided you give appropriate credit to the original author(s) and the source, provide a link to the Creative Commons license, and indicate if changes were made. 
success. Importantly, under the assumption that the Kazakhstani elite's policies toward and perceptions of the EU-as well as vice versa-are part of their broader and coherent understandings of their country's place in the world, this study widely resorts to relevant parallels for building and substantiating its arguments.

The paper primarily draws on a broad range of existing empirical studies on EU and Kazakh foreign policies (including those published in Russian), aiming to perform their systematic review in order to not only make their critical assessment, but also gain a more complete picture on the topic. In terms of structure, the article consists of three parts, successively discussing, first, the primary determinants of Astana's foreign policy in general, second, the driving motives of its behaviour toward the EU in particular, and third, factors contributing to Brussels' readiness to cooperate with Kazakhstan regardless of its regime remaining authoritarian. The study concludes by pondering on the role of pragmatism and identity in Kazakhstan's EU policies as well as the strengths, weaknesses and further dynamics of Brussels' power over Astana.

\section{Kazakhstan's foreign policy: Fundamental motives}

Even a brief look at primary sources and academic studies on Kazakhstan's foreign policy reveals its two primary characteristics, namely the prioritisation of economic goals and propensity to multi-vectorism (that is, collaboration with all regional powers), with the latter being consequential on the former. Both seem to emanate from the objective needs of Kazakhstan's development as well as the personal ideas of the country's elite and, in the first place, its long-standing autocratic leader, Nursultan Nazarbayev. Indeed, on the one hand, Kazakhstan's location in the center of Eurasia predetermines that the country would highly capitalise on the region's possible reconnection (Kuchins et al., 2015: p. 2). Moreover, being landlocked and situated distantly from the world's main communication channels makes it especially important for the country to have friendly relations with its neighbours (Bolekbaeva and Selivanova, 2015: p. 210). Concomitantly, what qualitatively distinguishes Kazakhstan from the other Central Asian states is its leader's strong personal dedication to the idea of economic modernisation, which dominates most of his speeches and addresses (Ambrosio and Lange, 2014), epitomising itself in his argument that "an open economy and integration into the world's powerful economic zones is the only means of survival for a nation and a state" (Nazarbayev, 1999, my translation). Nazarbayev's simultaneous commitment to economic modernisation and preservation of authoritarianism (discussed below) seems reminiscent of the developmental patterns of contemporary China and the so-called "Asian tigers" in the 1970-1990s. Incidentally, Nazarbayev himself contends he is influenced by the ideas of Lee Kuan Yew (Vanderhill, 2017: p. 47), Singapore's first prime minister who, for many, symbolises authoritarian modernisation. Nazarbayev's ideas are largely reflected in his policies which make him stand out among the region's leaders: Jarosiewicz (2016: p. 29), for example, considers him one of the few post-Soviet autocrats who tend to respond to a growing external and domestic pressure by acceleration of economic reforms rather than isolation and screw-tightening. ${ }^{2}$ Importantly, his economic reforms have resulted in a substantial growth of the middle class, reduction of poverty as well as increase in the average income per capita and monthly wages (for details, see ibid.: p. 22). In general, as the comparative study of Central Asian states by Batsaikhan and Dabrowski (2017: pp. 8-19) shows, Kazakhstan preforms best or second best among them across all economic and 
socio-economic indicators. This may substantially explain why Kazakhstan is one of the few post-Soviet states, where most people feel positive about the Soviet Union's break-up (Jarosiewicz, 2016:: p. 21).

Nazarbayev's economic motivations correlate well with his rejection of geopolitical competition, in particular, the ongoing so-called "New Great Game" in Eurasia (Konopelko, 2017: p. 3). In this vein, the Kazakhstani elite contest Putin's efforts to transform the Eurasian Economic Union (EAEU) from an economic to a political integration group (Kuchins et al., 2015: p. 9; Jarosiewicz, 2016: p. 27; Konopelko, 2017: p. 13; Patalakh, 2017: pp. 7-8). Simultaneously, Astana criticises US foreign policy for prioritising security and political issues over economic ones, arguing that Washington's harsh stances on Russia and Iran are detrimental to Kazakhstan's energy and economic needs (Kuchins et al., 2015: p. 9): incidentally, Nazarbayev personally decried the West's economic sanctions on Russia, calling them "barbaric" for being deleterious to Kazakhstan's economy (RFE/RL, 2015).

Another peculiarity of Nazarbayev is positive thinking inherent in his speeches: in this spirit, admitting the challenges in which Kazakhstan finds itself due to its geographical situation, he still tends to present them as an opportunity rather than a limit to the country's development (Ambrosio and Lange, 2014: p. 546). Foreign policy issues occupy, on average, $18.5 \%$ of Nazarbayev's annual addresses, the share which is comparable to Russian Presidents' addresses in the noughties, however, unlike them, Nazarbayev's are primarily devoted to economic issues (ibid: pp. 541-542). Rather than criticising any state's developmental model, Nazarbayev prefers speaking of comparative advantages which characterise each of them and which Kazakhstan, according to him, needs to integrate (ibid: p. 546). Apart from the obvious security motivation to keep good neighbourly relations with its two biggest neighbours, Russia and China (ibid: p. 549), Astana's approach toward them is largely driven by economic reasons. In a nutshell, Kazakhstan's interest in China is determined by, first, its developmental model, commonly attractive for autocracies, second, China's rapidly growing economy which provides a fruitful ground to the enhancement of mutual trade, and third, China's growing investments in the Kazakh economy-in the first place, infrastructure projects, the main of which is "The Silk Road Economic Belt" (Hug \& Zhang, 2010: pp. 6-7; Konopelko, 2017: p. 3). Importantly, all these also represent China's advantages over Russia, which further reinforces Astana's desire to collaborate with Beijing (Koch, 2013: p. 114). As for cooperation with Russia, Kazakhstan is chiefly motivated by the aspiration to find new markets (Nurgaliyeva, 2016: p. 95) and draw long-term benefits from the mutual economic integration (Kuchins et al., 2015: p. 9), ${ }^{3}$ the results of which, however, have been rather pessimistic thus far for Astana: not only has Kazakhstan's trade volume with the EAEU's members declined (Eurasian Economic Commission, 2017: p. 18), but also the Russia-West sanctions war and the Russian rouble's steep depreciation has pulled down the EAEU's other members, including Kazakhstan.

To justify the multi-vectorness, Nazarbayev bases his foreign policy on the ideology of Eurasianism, ${ }^{4}$ which, in his own words, presupposes that "our [Kazakhstan's] model for development will not resemble other countries; it will include in itself the achievements from different civilizations" (quoted in Engvall and Cornell, 2015: p. 69). One of the main components of his Eurasianism is a Eurasian Union, an integration group 
encompassing the former Soviet Union's states, the idea of which Nazarbayev expressed for the first time in 1994. As becomes clear from the analysis of his articles and speeches, his understanding of the union's basic principles has been practically invariable over time. Indeed, in 1994, 2004 and 2011, Nazarbayev methodically suggested that the then-future integration group should be grounded on economic pragmatism, voluntary membership, equality of its members and taking cognizance of differences in their developmental levels (Mostafa, 2013: pp. 164-165; Nurgaliyeva, 2016: p. 95). Unlike the Russian version of Eurasianism, which has a neo-imperial, anti-Western and anti-globalisation character (Mostafa, 2013: pp. 161-163), Nazarbayev's is formulated in a positive manner (i.e. from the in-favour-of rather than against perspective) and centres around economic integration, chiefly omitting the issues of ideology and security (ibid: 167; Nurgaliyeva, 2016: p. 97). In this vein, aiming to better engage Kazakhstan in international economic relations, he contends the integration group should, first, function as a platform for interregional cooperation (Mostafa, 2013: p. 165; Konopelko, 2017: p. 14) and second, be open for other states, among which he mentioned, in particular, Western countries (Nurgaliyeva, 2016: p. 97) and Turkey (Kuchins et al., 2015: p. 21). Primacy of economic considerations manifests itself in Nazarbayev's policies in the EAEU. For example, Nazarbayev advocates a careful approach to the pace of integration and the acceptance of new members, which is in a particularly marked contrast to geopolitically inclined Putin's Russia that calls for acceleration of integration and pulls other states into the union with little heed of the potential economic consequences of such moves (Patalakh, 2017: p. 7). Remarkably, whereas in Russia, Eurasianism is mostly a domain of-conservative and often marginal-intellectuals and is employed by the government only on ad hoc basis (Mostafa, 2013: pp. 161-163), in Kazakhstan, Eurasianism is not only an essential element accompanying various areas of the country's social and political life (for numerous examples, see Mostafa, 2013: p. 166), but also seems to be seated relatively deeply in people's minds and not dismissed as ideological bunkum. To illustrate, Kuchins et al. (2015: p. 3), having interviewed numerous Kazakh experts and officials, note that it is their common trait to identify their country as Eurasian.

Some studies (e.g. Engvall and Cornell, 2015; Jarosiewicz, 2016; Nurgaliyeva, 2016), however, appear to view the Russia factor as most critical in Kazakhstani foreign policy, sometimes going as far as reducing the entire policy of balancing to Nazarbayev's desire to ensure protection from Russia's possible aggression. Consider, for example, the following excerpts.

Kazakhstan's expanding partnership with China has been imperative for reducing its dependence on Russia (Engvall and Cornell, 2015: 68).

To reduce the dependency on Russia, Nazarbayev worked to create a favorable environment for foreign investors (Nurgaliyeva, 2016: p. 97).

Reforms are Kazakhstan's way of protecting itself from plunging into the zone of Moscow's civilisational, political and economic influence, from economic stagnation and the feudal socio-political order seen in Azerbaijan (Jarosiewicz 2016: p. 7). 
Economic cooperation with China, Russia's important economic partner, is intended to mitigate Moscow's aspirations in Central Asia, but also to boost the country's economic development (ibid: pp. 48-49).

At one level, accounts of this sort seem to possess a grain of truth: indeed, a number of empirical studies point to the Kazakhstani elite's growing considerations of sovereignty in light of Russia's coercive energy measures in the 1990s (Koch, 2013: pp. 112-113) as well as some concern they have about Russia's aggression in Ukraine (Kuchins et al., 2015: p. 10) and Kazakhstan's overdependence on Russia (Koch, 2013: p. 114). Moreover, Nazarbayev himself tends to praise China for pursuing a policy that is "aimed against hegemonism" (quoted in Engvall and Cornell, 2015: p. 68), which could be plausibly interpreted as criticism of Russian neo-imperialism. Also, especially in recent years, he has undertaken a number of-mostly symbolic, but still-steps arguably designed to reduce Russia's ideological influence in Kazakhstan and prevent Russian separatism in its northern regions (for details, see Holmquist, 2015: p. 2; Roberts, 2015: p. 5; Jarosiewicz, 2016: pp. 41-43).

Nonetheless, viewing this motive as primary would seemingly mean placing an overemphasis on its significance in Astana's foreign policy which, in fact, would apparently be of little difference had Russia no neo-imperial ambitions. First, such accounts underestimate the important role of the considerations of economic development and modernisation, deeply rooted in Nazarbayev's thinking, as well as the EU's (discussed below) and China's high instrumental value for these goals. Second, as some scholars rightly point out, in Central Asia, the EU does not possess-and does not even try to possess-hard power capabilities comparable to those of Russia (e.g. Kuchins et al., 2015; Konopelko, 2017). Hence, for Astana, closer ties with the bloc may hardly serve as a workable counterbalance against Moscow, especially considering that in 2014, the bloc failed to protect even Ukraine, a country whose ties with the EU are far closer than those of Kazakhstan. Third, should reducing Moscow's leverage be Nazarbayev's primary motive, he would not have likely entered the Russia-led Customs Union and its successor, the Eurasian Economic Union (EAEU), thus dramatically heightening its level of dependence on Russia-all the more so given that the Customs Union was initiated in 2009, a year after the Russian aggression in Georgia, and the treaty on the EAEU was signed in May 2014, at the peak of the RussoUkrainian conflict. Fourth, in case of a revolt, Putin is perhaps the only one that may try to save Nazarbayev's regime, similarly to how he acts in Syria. In view of this, it comes as no surprise that the two countries enhanced their cooperation in 2011, against the backdrop of the Arab Spring and intensifying protests in Russia (Engvall and Cornell, 2015: pp. 69-70). ${ }^{5}$ Fifth, Moscow hardly appears in a position to repeat the Crimean scenario in Northern Kazakhstan: as empirical analysis shows, potential pro-Russian irredentism in that region, while not impossible, is still limited (Diener, 2015), which starkly contrasts with the pre-2014 Crimea, where separatist notions, already strong, were being further inflamed by the Kremlin's activities (Roslycky, 2011). Last, in light of the growing discontent among ordinary Kazakhs about China's increasing influence in their country, coupled with their generally positive view of Russia (Koch, 2013), Astana's friendship with Moscow seems itself to be a balancing act with regard to Beijing. 
Consequently, it appears fairer to deem Russia as a factor limiting Kazakhstan's foreign policy options rather than determining them. This point can be illustrated on Kazakhstan's foreign policy freedom in security sphere which Ambrosio and Lange (2014: p. 550) describe as "more aspirational than practical". For one thing, Astana refrains from getting involved in any form of military collaboration with Beijing for such may engender a harsh reply from Moscow (ibid). In a similar vein, Kazakhstan's cooperation with NATO, although substantial compared to those of the Central Asian states, is still limited, in large part because Nazarbayev realises the alliance will never have the same influence in the region as Moscow (Kuchins et al., 2015: pp. 17-19) and hence, for him, the possible danger this cooperation produces exceeds the benefit it gives.

\section{Kazakhstan's approach to the EU: Key determinants}

Kazakhstan's approach to the EU can be probably best summarised by the word "instrumentality" which for the Kazakhstani regime is apparent in two aspects. The first of them is the bloc's perceived competence, that is, the available knowledge, technologies and investment which Nazarbayev needs for Kazakhstan's economic development and modernisation. Importantly, the EU's competence manifests itself both against the absolute standard as well as compared to the other regional powers: Koch (2013: p. 112), for instance, notes that "the strategy of encouraging Western involvement in the resource economy [was] a response to concrete economic conditions in the early 1990s, and the fact that Russia lacked sufficient financial capacity and technology to develop Kazakhstan's immense oil resources". ${ }^{6}$ Indeed, the idea of the EU being advanced and competent is pronounced in Kazakhstan's official discourse with Nazarbayev elsewhere citing the need to utilise European experience in various areas, such as judicial system (Vremya, 2017), education (Tengri News, 2014), EAEU integration (Forum, 2014) etc. Perhaps the most vivid example in this regard is the 2009-2011 "Path to Europe" national program which Nazarbayev personally initiated to enhance all-round cooperation between the EU and Kazakhstan and use "positive European experience" across multiple spheres (President of Kazakhstan, 2008). Europe and the West top the list of the regions which Nazarbayev mentions in his addresses, with the majority of those references dealing with the economic sphere and being dedicated to such international organisations as the EU, the OSCE and the EBRD (Ambrosio and Lange, 2014: p. 543). Also, Astana resorts to the help of Western consultants to conduct economics reforms: since 2011, for example, one of them has been "Tony Blair Associates", a company owned by former British Prime Minister. ${ }^{7}$

Consistent with the competence argument is also the fact that Astana appears to need partnership with Brussels more than vice versa. Analysing EU-Kazakhstan relations in the two recent decades, Kurmanguzhin (2016: pp. 107-114) shows that it is Astana that has primarily been pushing them forward, suggesting initiatives that were often ahead of the bloc's the then approaches to cooperation with Central Asia. Moreover, a closer look at Astana's major initiatives, made in 2000, 2006, but especially in 2009-2014, during the work on EPCA, makes it clear that their focus was on the longterm investment, economic and energy collaboration (2015: pp. 36-40; 2016: p. 107, 109). Some propositions also regarded political cooperation and democratisation, yet those were rather of auxiliary character and furthermore, Nazarbayev's sincerity in their 
regard may be generally called into question given his reluctance to carry out any substantial political reforms in Kazakhstan (see below).

Notably, instrumental competence seems to determine Astana's approach toward the West in general, of which the EU is-perhaps the most illustrative, but stil-only a particular instance. To illustrate, elaborating on Kazakhstan's aspiration to cooperate with its second largest FDI source, the US, one interview-based qualitative study points out that

Kazakh elites emphasize that the United States possesses competitive advantages in technology, business and legal best practices, institutions, and overall values that, if applied in the region, would be beneficial to its long-term development (Kuchins et al., 2015: p. 18).

Also, in contradistinction to the other Central Asian countries, whose collaborations with NATO are constrained to the Partnership for Peace program, Kazakhstan also participates in the alliance's Planning and Review Process and has agreed NATO's Individual Partnership Action Plan and Partnership Action Plan against Terrorism. Despite certain negative outcomes that partnership may bring about, given Kazakhstan's membership in the Russia-led Collective Security Treaty Organisation (see Shaymergenov and Biekenov, 2010: pp. 37-38, 47), the country still engages itself in NATO's initiatives, viewing them as a way to train and modernise its national army in accordance with the best world standards and enhance its prestige through participation in international peacekeeping operations (for details, see ibid: pp. 39-44).

The second dimension of the EU's instrumentality relates to Nazarbayev's wide image-promotion campaign which serves him not only to attract investments, but also, importantly, to legitimise his regime. ${ }^{8}$ For this goal, the usefulness of the West in general and the EU in particular is determined by the fact that they seem to symbolise, in Nazarbayev's view, progress and modernity. In this respect, even his positioning of Kazakhstan as a Eurasian rather than a Central Asian state should be most likely interpreted through such lenses. In this respect, in 2014, Nazarbayev went even further, suggesting to rename Kazakhstan to "Kazak Eli" to get rid of the "stan" suffix that, according to him, makes the country poorly distinguishable from its neighbours, pushing off tourists and investors (BBC News, 2014). ${ }^{9}$ To promote the image of Kazakhstan as a forward-thinking country, in recent years, the Nazarbayev regime has been especially active in hosting big international events, such as the 2011 Asian Winter Games, EXPO-2017 etc. Importantly, from the Kazakhstani elite's pegrirspective, such events appear to serve, in the first place, the goal of image-enhancement, aiming at economic development only to a lesser extent. Indeed, as Nurmakov (2016: 121-123) shows, the messages accompanying those events represent the goals and the will of the ruling class with little consideration of the public's desires, mostly addressing foreign governments and investors and not tourists, as officially claimed by the government. Moreover, most of such events take place in the country's most developed cities, making little, if any, contribution to bridging the gap in regional disparities. 
Also, Kazakhstan widely uses its membership in international (primarily, Western) fora for the purposes of nation-branding ${ }^{10}$ and regime legitimation-or, put another way, "[t]he legitimacy of the Nazarbayev regime, in the post-2007 years, became, inter alia, the function of the degree to which Kazakhstan is formally engaged with Western-sponsored initiatives related to the human dimension" (Anceschi, 2014: p. 17). For example, researchers commonly note that Kazakhstan has largely portrayed its 2010 OSCE Chairmanship as the evidence of the country's being a reliable member of the international community. Yet, again, as scholars widely argue, albeit the chairmanship was coupled with political and human rights reforms within the framework of the 2009-2012 National Human Rights Action Plan, they turned out to be mostly cosmetic, failing to make real improvements (Hug and Zhang, 2010: p. 10; Engvall and Cornell, 2015: 44-47; Tsertsvadze and Axyonova, 2013: 1; Bossuyt and Kubicek, 2015: pp. 186187; Kuchins et al., 2015: p. 20). This discussion brings us to the need to take a closer look at the EU' perception of Kazakhstan, which is done below.

\section{Kazakhstani political regime and Brussels' approach to Astana}

According to Kembayev (2016: p. 202), Kazakhstan's poor record on democracy and human rights is the primary factor which hinders the deepening of the Brussels-Astana relations. As he puts it, the mutual dialogue in this field, unlike in the security area, "cannot be qualified as harmonious" (ibid: p. 194), given that the EU continuously has concerns in this regard (ibid). Yet, this notwithstanding, the overall approach of the bloc toward Astana remains positive ${ }^{11}$ : indeed, despite an autocratic regime, the EU conceives of Kazakhstan, in the words of Kavalski and Cho (2017: p. 6), as "[a] potentially promising pupil[]" in the Central Asian region (along with Kyrgyzstan). Researchers largely note that the bloc's officials commonly appreciate Kazakhstan's ambitiousness, influentiality and predictability (Bolekbaeva and Selivanova, 2015: p. 226), calling the country the region's "anchor of stability" (Kuchins et al., 2015: p. 21) and prizing its reliability as an energy partner (Konopelko, 2017: p. 7). Remarkably, in 2014, at the peak of the Ukrainian crisis, when Putin's Russia was being highly isolated, European leaders and high-ranked officials-for instance, François Hollande and German Foreign Minister Frank-Walter Steinmeier-paid official visits to Kazakhstan to discuss, first, their countries' own cooperation with Kazakhstan, in particular in the energy and infrastructure areas, and second, the possibility of Astana serving as a possible host of Russian-Ukraine peace talks, the plan which, however, was never actualised, for all rounds of those talks eventually took place in Minsk instead (Engvall and Cornell, 2015: 70; Kuchins et al., 2015: p. 21). ${ }^{12}$

What has contributed to the EU's overall positive attitude to cooperation with Kazakhstan? The first reason seemingly consists in the country's progressiveness relative to its Central Asian fellows. More precisely, Kazakhstan appears to be the sole stable well-to-do Central Asian country with an open foreign policy: indeed, while Kyrgyzstan and Tajikistan are too poor, Uzbekistan and Turkmenistan are too withdrawn and inclined not to follow the rules of the game (Dave, 2007: p. 4; Kuzmina 2014: p. 5). Furthermore, notwithstanding a poor democracy record in absolute terms, Kazakhstan is the region's second most democratic country after Kyrgyzstan (EIU, 2017), thanks to which the EU, guided by the principle of "not put[ting] all Central 
Asian countries within the same authoritarian basket" (Anceschi, 2014: p. 16), tends to somewhat close its eyes on electoral fraud in that country.

The second factor deals with the behaviour of Kazakhstan itself, which set it apart from the other post-Soviet autocracies. On this point, Nazarbayev is emblematic of what Hug (2009: p. 3) calls "smart authoritarianism", i.e. utilising pronouncedly temperate methods to stay in power, "not boiling his opponents, but using the levers of power to more subtly suppress dissent". Indeed, the comprehensive analysis done by Vanderhill (2017: pp. 46-48) shows that, in contrast with some of his fellow autocrats, Nazarbayev tends to justify his right to rule by real socioeconomic results rather than pure repressive measures, use comparatively lenient ways to block access to information (e.g. in Kazakhstan, foreign websites do not get blocked and local ones get restricted only sometimes), allow foreign NGOs to work in the country and fund national NGOs. Also, Kazakhstan somewhat resists adopting Russian-like restrictions on civil society, especially when it comes to the issues salient for Western audience. In this vein, the Nazarbayev administration avoids supporting the harsh stance on gay rights promoted by Russia, both at home and internationally (for examples, see Patalakh, 2017: pp. 6-7). In other instances, Kazakhstan passes softer versions of Russian regulations: such is the case with the recent Kazakhstani law on NGOs which places certain restrictions on them, but, unlike a similar Russian law, does not oblige NGOs receiving international funding to get registered as "foreign agents", an expression meaning "spies" in Russian (EurasiaNet, 2015).

Kazakh political scientist Rustem Kurmanguzhin (2016: p. 110) argues that the Kazakhstani government considers democratisation as a long-term goal which should be attained gradually and where external intervention is counterproductive. He also points to the fact that Kazakhstan's 2009-2011 "Path to Europe" program contained reforms in the country's electoral legislation, thanks to which, inter alia, the national parliament was transformed into a multi-party one (ibid: p. 113). Yet, arguments of this sort should apparently be regarded with a grain of salt, bearing in mind that in recent years, as international rankings show, Kazakhstan has become even more authoritarian. For instance, in Democracy Index, the country's score decreased from 3.30 (132nd rank) in 2010 to 3.06 (139th rank) in 2016 (EIU, 2010: p. 7; 2017: p. 10), its Freedom score worsened from 5.5/7 in 2010 to 6/7 in 2017 (Freedom House 2010a, 2017a) and its press freedom score deteriorated from 78/100 in 2010 to 85/100 in 2017 (Freedom House 2010b, 2017b). Moreover, many of those policies are likely to have been part of Nazarbayev's PR campaign. Such is, for instance, the case with the "Path to Europe" program, the adoption of which was overtly linked to Kazakhstan's upcoming OSCE chairmanship (President of Kazakhstan, 2008). Remarkably, the program included a humanitarian dimension, yet, hardly considering it a priority: not only it was listed last, but also, while officially it was aiming to develop the social partnership institution, tolerance and liberal attitude toward other religions as well as use European experience in gender policy (ibid), in fact, in implementing those provisions, the government confined itself solely to organisation of four conferences and attraction of volunteering organisations from Europe to develop the institution of volunteering in Kazakhstan (Government of Kazakhstan, 2008). This program seems to illustrate Nazarbayev's general approach to human rights initiatives, with regard to which, as one interviewbased study notes, 
the Kazakh authorities' working agenda is punctuated by . . . 'strategic deadlines'. Those coincide with major bilateral events such as high-level conferences or review meetings. Once a conference or a meeting of this type is over, the implementation and follow-up of agreed-upon activities tends to be put on hold or slows down fundamentally because of bureaucratic obstructionism and the lack of political will (Voloshin, 2014: p. 48).

Therefore, more compelling is the argument of Dave (2007: p. 6) that deems Nazarbayev's political reforms as instrumental, directly linking them to the West's pressure and noting that they have mainly led to the regime's further strengthening thus far despite that they have laid some foundation for a possible democratisation in the future. Hence, it is open to debates whether Nazarbayev's devotion to modernisation in general should necessarily be regarded as a sign of lofty ideals, given that, despite the innumerability and magnitude of his reforms (for their overview, see Jarosiewicz, 2016: pp. 30-32, 45), they hardly touch his personal leadership. In view of this, some authors suggest that Nazarbayev and his elite need economic reforms because economy is the source of their own enrichment as well as the foundation of the legitimacy of their rule, noting that the Kazakhstani regime is based on an unwritten "social contract" which implies that society stays silent on the authoritarian regime, getting in return peace, stability and relatively high income (Koch, 2013: p. 115; Jarosiewicz, 2016: pp. 23-24).

The "smartness" of Nazarbayev's authoritarianism is especially striking in Kazakhstan's approach to the EU, especially if viewed in comparison with the other post-Soviet autocracies. For instance, the country's high officials actively work with the Western audience by publishing in international magazines articles arguing that Kazakhstan is a democratic state (e.g. Idrissov, 2011) and proudly highlighting Astana's accomplishments in establishing close economic ties with the EU (e.g. Nazarbayev, 2014). More importantly, instead of resolutely rejecting EU suggestions on human rights, like other post-Soviet autocracies tend to do, Kazakhstan tends to treat them with conspicuous consideration and politeness. In 2011, for example, EU and US criticism induced Nazarbayev to refrain from holding a referendum on the prolongation of his presidential term till 2020. Later, answering to remarks about violations at the 2011 presidential elections, Astana promised to make improvements, a behaviour which at that time was in a stark contrast to the overtly falsified 2010 Belarusian elections and violently stifled protests after them (Sivokin, 2011). In general, when accused of human rights violations, Astana tends to politely reply in a manner that-at least to some extent-recognises democracy and human rights as values, acknowledges Kazakhstan's underdevelopment in this regard compared to the West, and accepts the need to improve. At worst, Nazarbayev, similarly to other postSoviet leaders, asks to respect Kazakhstan's internal traditions, but still using a polite language. In July 2013, for instance, he responded to a British journalist as follows: "We are grateful to you for the advice, but no one has the right to instruct us as to how to live and how to build our country" (Savchenko, 2015). In other cases, Nazarbayev endeavours to shift the attention from Kazakhstan's weakness toward its achievements: in this vein, in March 2016, Nazarbayev gave the following reply to Jean-Claude Junker's remark about human rights in Kazakhstan: 
[The EU] is a very important, both economic and political, partner [of Kazakhstan]; therefore, we take very positively all friendly advice of my friend, Mr Junker, regarding the political situation [in Kazakhstan] and so forth. I am grateful to you for congratulating me on last year's elections and this year's parliamentary elections, when observers from 60 countries, who amounted to over a thousand, said our elections are held on the full basis of democracy, freedom, competition and adherence to all the laws which are necessary in such cases (Radio Azattyq, 2016, my translation).

To draw a parallel, in such cases, Putin widely resorts to blaming the West for double standards (for details, see Headley, 2015), ${ }^{13}$ while Belarusian President Alexander Lukashenko tends to have recourse to overt insults: to exemplify, in 2011, when the then President of the European Commission José Manuel Barroso accused him of human rights abuse, Lukashenko gave the following comment:

On the subjects of bastards like Barroso and others - who is Barroso anyway? There was a Barroso in Portugal. But they kicked him out and put him to work in the European Commission. The last thing I want to know about European officials is who said this or that. There are thousands of them. They're all crooks. So I don't want to talk about any Barrosos or other bastards like that (Rettman, 2011).

Furthermore, Astana agrees to participate in the EU's human rights dialogues (HRDs) which, according to (Anceschi, 2014: p. 16), go far smoother than the bloc's HRDs with, for instance, Turkmenistan. Likewise, in 2011, Kazakhstan agreed to take part in the 2011 Civil Society Seminar in Almaty, where the other Central Asian delegations declined to take part (ibid: p. 17). However, again, the Nazarbayev regime's participation in the HRDs should be viewed in terms of its aforementioned desire to seek legitimation rather than democratise. In this vein, Anceschi (ibid: p. 16) notes that Astana tends to-quite successfully-marginalise the most disputable matters at HRDs. Similarly, as the analysis of the agenda of Kazakhstan's 2010 OSCE chairmanship shows, the regime managed to shift the focus from democracy and human rights in their liberal sense to the issues of security, environmental security, interethnic and interreligious relations, illegal labour migration etc. (Faizova, 2011). In their analysis of how the Kazakhstani and EU elites depict each other, Ospanova et al. (2017: p. 79) point to a general difference in the areas the two sides accentuate: while Kazakhstani politicians mainly concentrate on bilateral economic and energy ties, the EPCA and the facilitation of the visa regime, largely underlining their country's role in improving the bilateral collaboration, EU officials focus more on Kazakhstan's reforms of the rule of law and regional governance, making no mention of visa regime simplification. In like manner, while describing the EU, the Kazakhstani elites primarily highlight its achievements on the integration path, in building a single market and reaching a high status in the world economy, whereas European officials tend to put the emphasis on the value-based nature of the bloc (ibid: pp. 79-80). Declining international organisations' human rights reports as allegedly biased and imposing Western standards, Astana resorts to creating national commissions which take an "alternative perspective" of democracy and human rights to defend the regime (Savchenko, 2015). Such is largely in accord with 
Nazarbayev's alternative narrative on democracy which, following the summary of Vanderhill (2017: 47), rests on

1) arguing that liberalism or democracy must be a gradual, evolutionary development in Kazakhstan and that political stability is more important than immediate reform; 2) using the language of democracy to describe the political regime in Kazakhstan; 3) claiming that the process of democratization in other countries has resulted in violence, instability, and economic hardship; 4) arguing that external involvement or pressure is inappropriate and not conducive for democracy.

Even a brief look at this alternative narrative reveals certain contradictions between its elements, which seems to mean that the Kazakh regime has little intention to present any coherent replacement of the common understanding of democracy, but rather, aims to exploit any appropriate argument to halt it. This notwithstanding, as opinion polls show, the Kazakhstani public at large mostly accept-or at least report the acceptance of-this official narrative, believing that their country is democratic (or moving toward democracy) and needs a strong leader (see ibid.: p. 49 for details). Similar contradictions are evident in Kazakhstan's approach toward Europe as well. On the one hand, Nazarbayev generally follows the international community's rules of the game, uses Kazakhstan's OSCE chairmanship and friendship with the EU for his own PR and tries to convince Europe of his regime's being democratic, On the other, he sometimes rejects democratisation attempts, labelling them as pressure and intervention, as reflected in statements like "[w]e have seen attempts to use instruments such as observer missions during national elections to apply pressure by one group of countries on another" (quoted in ibid.: p. 48). To give a similar example, in 2011, Astana threatened to designate persona non grata one European parliamentarian that had visited the city of Zhanaozen after the massacre (Anceschi, 2014: p. 15; see endnote 2 for further details on the Zhanaozen massacre).

The third factor relates to the EU's perception of and interest in Kazakhstan. One significant aspect of this factor is the relative unimportance of Kazakhstan for the bloc, which is a manifestation of the EU's general treatment of Central Asia, ${ }^{14}$ the region that Kavalski and Cho describe as "[a] ghost[] in the vacuum of the EU's external affairs" (2017: p. 3) and "merely a bridge (if not-quite literally-a mere refueling station) between the EU's other and strategically more important commitments" (ibid: p. 4). On the one hand, such may appear puzzling, given that the EU-unlike the US, Russia and China-possesses a well-defined long-term formal strategy which delineates its priorities in Central Asia. Yet, because of the region's distance from the EU, both in geographical and political terms-in the 1990s, Brussels remarkably perceived it as a Russian sphere of influence-as well as integration-related problems inside the bloc and problematic interstate relations in Central Asia, the bloc's policies in that region tend to be, as Kavalski and Cho put it, "lack[ing] focus" and "largely reactive" (ibid: p. 4; see also Kuzmina, 2014: p. 4). A good manifestation of this point is that fact that the EU elaborated a common strategy toward the region only in 2007, sixteen years after the Soviet Union's break-up. ${ }^{15}$ The Strategy's adoption itself was, as phrased by Voloshin (2014: pp. 43-44), "a concerted attempt to recalibrate the EU's ties on a modified basis where realism and idealism no longer contradict each other". Such reflects the bloc's 
failure to view democracy promotion in Central Asia as its moral duty (Kavalski and Cho, 2017: p. 4) -all the more so because its current priority in this respect is the Western Balkans (ibid: p. 10) ${ }^{16}$ and because EU members generally feel Central Asia lacks breading ground for democratisation (Bossuyt, 2016). In this light, it comes as no surprise that the EU allocates relatively scarce resources on the region's democratisation (Voloshin, 2014: p. 45), the mission of the EU's Special Representative for Central Asia is, as Kavalski and Cho (2017: p. 10) put it, "understaffed and underfunded" and in general, the bloc mostly opts to deal with the region "together [through] coordination among international structures" (quoted in ibid). ${ }^{17}$ Also, with respect to various EU documents on Central Asia, such as the 2007 Strategy and Indicative Programme, the 1999 PCA, the new EPCA etc., researchers widely point out that they mostly contain general phrases, being vague on specific actions concerning democracy and human rights and failing to clarify conditions linking EU assistance to compliance with democratic norms (Hug and Zhang, 2010: p. 4; Tsertsvadze and Axyonova, 2013: p. 2; Voloshin, 2014: p. 46; Bossuyt and Kubicek, 2015: p. 178). Interestingly, that the EU treats Central Asia as a region of secondary significance seems to epitomise a larger trend, beneficial for the Nazarbayev regime. Indeed, while China and Russia are mainly involved in a rivalry with the West in East/Southeast Asia and Eastern Europe correspondingly, Kazakhstan finds itself in an opportune position of a country with which major powers want to collaborate, simultaneously paying relatively little attention to it.

Of higher salience, however, seems another aspect, namely the EU's instrumental need of Kazakhstan. Indeed, scholars widely use the word "pragmatic" to describe not only Astana's approach toward Brussels, but also Brussels' interest in Astana. Gubaidullina (2001: p. 36), for instance, defines the two approaches as "attendant pragmatism" and "liberal pragmatism" respectively, while Anceschi (2014: p. 21) goes even further, referring to the entire EU-Kazakhstani ties as "a tyranny of pragmatism" (for similar accounts, see Malysheva, 2010), noting that it is energy issues that are at the core of bilateral agenda while values and democracy are of marginal importance (ibid: p. 16). Some researchers (e.g. Akkazieva, 2012: p. 220; Kuzmina, 2014: p. 5; Voloshin, 2014: p. 55) note that the bloc's main interest-in Turkmenistan as well as Kazakhstan-lies in the energy sphere, in line with the diversification of its energy supply: with these two states, the EU signed Memoranda of Understanding regarding energy issues as early as in 2006 and 2008 respectively. ${ }^{18}$ Of some importance for the EU are also infrastructure, given that routes for the growing EU-China trade run through Central Asia, and security sphere, for Brussels deems Central Asia as, first, a transit corridor for the smuggling of narcotics from Afghanistan and, second, a region where political destabilisation may produce terrorism and extremism (Akkazieva, 2012: p. 220).

To enhance their attractiveness as investment recipients, the EU seeks to advance Central Asian states' financial stability and economic reforms as well as their further integration in the world economic and financial systems (Kuzmina, 2014: p. 7). Accordingly, in its policies toward Central Asia, the bloc, as the indicative programmes of its Development Cooperation Instrument suggest (European Commission, 2007, 2011, 2014), primarily concentrates on the furtherance of regional collaboration and good neighbourly relations, improvement of living standards and lessening of poverty as well as energy, environmental and water projects. Incidentally, the 2007 Strategy also mentions human rights and democratisation as dimensions of the EU's activities, but they 
are coupled with good governance (Council of the EU, 2007: pp. 7-9), to which the EU, as some researchers argue, tends to give priority. Meden (2012: p. 59), for instance, points out that Brussels is shifting its focus from democracy promotion to fight against corruption, on paper, however, continuing to demand democratisation. Likewise, (Bossuyt and Kubicek, 2015: p. 178) note that the budget of the European Instrument for Democracy and Human Rights for Central Asia is relatively scarce and within the framework of the Development Cooperation Instrument, $60-90 \%$ of aid is devoted to poverty reduction, economic reforms and good governance.

Hence, prioritisation of stability over human rights ${ }^{19}$ reflects the bloc's overall attitude to the entire region, yet, this particularly manifests itself in relation to instrumentally important states. In this spirit, in 2008-2009, the EU removed all economic sanctions from Uzbekistan, even though its regime had hardly shown any improvements in its treatment of human rights following the violent suppression of protests in Andijan in 2005. Commentators largely interpreted that decision pointing to Uzbekistan's significance as the host of a German military base and a potential gas supplier for the Trans-Caspian gas pipeline, the idea of which the bloc was being actively promoting at that time (Malysheva, 2010: pp. 31-32; Voloshin, 2014: p. 49). By the same token, the study of (Bossuyt and Kubicek 2015) contends that in Kyrgyzstan, the EU is comparatively more active on advancing liberal democracy than in Kazakhstan, where the bloc primarily promotes conditions which may lay the long-term foundation for it, such as administrative capacity of the state: hence, instead of increasing pressure and demands on Nazarbayev, Brussels prefers cooperating with him on the issues he welcomes. Among the reasons for this difference, the authors mention Kazakhstan's importance relative to resource-poor Kyrgyzstan, the fact that the Kyrgyz government asks for some help in democratisation whereas Astana rejects it as well as the fact that a possible instability in Kazakhstan may have more negative consequences for the region than instability in Kyrgyzstan (ibid).

\section{Concluding remarks}

The study has shown that Kazakhstan's cooperation aspirations vis-à-vis the EU are largely dictated by instrumental considerations of economic modernisation and regime legitimation, corresponding to the general multi-vectorism of its foreign policy. Moreover, the success of Nazarbayev's EU policies is possible to a great extent thanks to Brussels' concomitant positive stand on friendship with Astana, which stems not only from the relatively high instrumental value of Kazakhstan for the bloc and its generally passive approach to democracy promotion in Central Asia, but also because of Kazakhstan's being more progressive and pro-European in comparison with the region's other states. This argument is in line with (Anceschi, 2014: p. 21) conclusion that "pragmatism may be viewed as the essential glue of the entire relationship between the European Union and Kazakhstan", a statement which, however, seems to necessitate further specification, for the very assertion that Astana pursues a pragmatic foreign policy $^{20}$ may be interpreted in multiple ways. Indeed, depending on an IR study, the notion of pragmatism may pertain either to an actor's preferences (referring to practical rather than ideological considerations) or an actor's methods (synonymously with such words as "instrumental", "useful", "expedient"). Accordingly, one can observe commonalities and differences between the foreign policy of Kazakhstan and those of other 
states which researchers also describe as "pragmatic". Unlike "pragmatic" Uzbekistan (Sayfullayev, 2016) and Azerbaijan (Makili-Aliyev, 2013), both of which carry out isolationist policies so as not to fall into the orbit of any big player, Kazakhstan, contrariwise, endeavours to open up to the world, actively participating in international organisations and integration groups. While Tashkent has U-turned its foreign policy orientation at least twice in the two recent decades, Astana tries to conduct a steady and predictable foreign policy. Unlike Qatar, whose foreign policy Khatib (2013) describes as pragmatic in the sense that it rests on short-term needs and contains incoherences, Kazakhstani foreign policy, contrariwise, is driven by long-term interests and involves considerable planning. Similarly to the pragmatism of Indian foreign policy_-meaning "a rejection of . . . 'idealism' or 'moral posturing' and, instead, a focus on power and material interests" (Miller and De Estrada, 2017: p. 27)-Nazarbayev, while not overriding ideology completely, uses it not to derive his decisions from it, but, rather, to support what he wants to do on the basis of material interests. Such seems identical to what Khan (2014: p. 1) refers to as Obama's "liberal pragmatism" which was grounded in the "understanding the realities of the situation and making decisions based on thorough research of these realities".

This is not to say that Kazakhstan's relations with the EU are completely unrelated to its identity: having friendly relations with the bloc corresponds to its self-portrayal as a Eurasian state and a bridge between the West and the East. On this point, however, noteworthy is that the notion of a bridge can be found in the official discourses of many states, each of which, again, uses it in a particular way: while the Serbian elite utilise it to balance the instrumental and identity-based foreign policy needs (Patalakh, 2018) and the Putin regime exploits it to dissociate itself from the West and justify Russia's "great power" status amidst the decline of its influence after the Soviet Union's collapse (Svarin, 2016), Astana applies it preponderantly for the purposes of domestic modernisation, to justify its close collaboration with multiple actors with the aim to capitalise on their competitive advantages. A number of studies maintain that in Central Asia, Kazakhstan possesses the strongest European identity (e.g. Engvall and Cornell, 2015: p. 57), one of the manifestations of which is that its elite openly criticise the legacy the Soviet Union left in their country (Jarosiewicz, 2016: p. 40). ${ }^{21}$ The idea of Kazakhstan having a European identity, however, should be considered with a reservation, since Kazakhstan hardly falls into the group of post-Soviet states whose strong and wide-ranging self-identification with Europe is coupled with their rejection of Russia which they deem as a barbaric, uncivilised state. ${ }^{22}$ In Kazakhstan's case, friendship with the EU, even though fervently desired, appears to be simply instrumental to the dominant official narrative of the country striving to be progressive and modern-mostly in the economic and technological areas-and therefore, is limited to these areas. Hence, for Astana, collaborating with Brussels per se seems to have little to do with selfidentification and is largely delinked from the Kazakhstani elite's emotional perception of the EU as well as other actors. Concurrently, it is connected to their conception of the bloc's strengths relative to other actors-again, primarily in the areas that interest them.

Yet, one may wonder whether this state of motives is stable and whether it is possible that in the mid or long term, Kazakhstan, identically to Russia, will end up having a strong anti-Western identity, all the more so because analogies between present-day Kazakhstan and Russia during Putin's first two presidential terms are often cited (e.g. ibid.: p. 23). From the viewpoint of domestic factors, such seems unlikely, since the 
Kazakh society lacks the imperial ambitions which are deeply rooted in Russians, making Putin's anti-Westernism especially effective. Yet, the foreign policy of Kazakhstan, similarly to those of other post-Soviet autocracies, largely hinges on the ideational beliefs of the incumbent leader, due to which some states (e.g. Belarus) are or were engaged in a long-term confrontation with the West with no imperial ambitions. From this perspective, since Nazarbayev has concentrated all power in his own hands and has yet to nominate a successor, which researchers consider to be one of his main drawbacks (e.g. ibid.: p. 6), it is barely possible to foresee whether Kazakhstan's next leader will share Nazarbayev's foreign policy beliefs. ${ }^{23}$

For Brussels' power over Astana, the current configuration of Kazakhstan's motives represents both opportunities and limitations. For example, one may assume that the Nazarbayev regime will undertake more profound democratisation if the occurrence of certain changes in external or internal factors enhances the bloc's instrumental value for and, consequently, its leverage over Astana. In this respect, one may draw a parallel with the West's efforts to push for transparency in Kazakhstan which had been largely fruitless until 2014-2016, when a worsening economic situation induced the country's government to initiate major institutional reforms in that regard (Öge, 2017). Likewise, Nazarbayev's enthusiastic push for rapprochement with the bloc in 2009-2010 was arguably associated with negative consequences of the 2008 financial crisis for Kazakhstan (Kurmanguzhin, 2016: p. 111). The opposite tendency also seems to be at play. Ospanova et al. (2017: p. 78), for instance, note that in 2011-2013, the official framing of the EU in the Kazakhstani media was more negative than before and after, with the emphasis being put on the bloc's inability to cope with the Eurozone crisis, shortage of solidarity and growing social tensions between its members. Approximately at the same period, as pointed out by Tsertsvadze and Axyonova (2013: p. 1), Kazakhstan's interest in the EPCA was seemingly diminishing. Both observations are suspiciously simultaneous with the EU's the then arguably increasing demands of a stronger commitment to democracy ( ibid) and the above-mentioned Russia-Kazakhstan rapprochement, related to the unfolding Arab Spring and the Zhanaozen massacre. Interestingly, since Brussels' approach toward Astana specifically and Central Asia in general is also substantially determined by instrumental benefits, shifts in the bloc's stance toward the region have also been commonly related to changes in external conditions which augmented the region's instrumental value for the EU. For instance, after 9/11, the EU's (and the West's in general) focus toward the region increased because of the incipient international operation in Afghanistan (Kavalski and Cho, 2017: p. 6).

A number of NGO researchers (Dave, 2007; Fülscher, 2007; Hug and Zhang, 2010; Tsertsvadze and Axyonova, 2013; Boostra and Tsertsvadze, 2016) and academic scholars (Konopelko, 2017) suggest the EU take a harsher stance on democracy and human rights promotion in Kazakhstan, which generally seems somewhat idealistic, ${ }^{24}$ given that they all concomitantly note that Brussels can hardly use its conditionality if there is no membership opportunity for Kazakhstan. Those scholars fairly point to the fact that the bloc has some leverage over Astana, which stems from the fact that Kazakhstan cares about its international image (Hug, 2009: p. 16), ${ }^{25}$ is afraid to be completely locked into the EAEU and is economically connected too closely to the EU (Boostra and Tsertsvadze, 2016: p. 8). Thus far, however, Nazarbayev's regime seems to have generally succeeded in mitigating it even when and where Brussels was in a 
stronger position. For example, even though NGOs commonly advised the bloc to use its leverage in the talks over EPCA (e.g. Tsertsvadze and Axyonova, 2013: p. 2), Astana eventually managed to get the long-hoped-for agreement with only cosmetic political reforms. What seems to limit the EU's power over Astana is not only the skilfulness of Nazarbayev's diplomacy and the bloc's interest in Kazakhstan as an energy partner, but also the fact that Astana's multi-vectorness leaves it options to manoeuvre, a factor due to which Brussels tends not to exert too much pressure on Astana not to induce it to exchange its partnership with the bloc for closer friendship with Russia and China (Fülscher, 2007: p. 3; Bossuyt and Kubicek, 2015: p. 183). Also, some authors (e.g. Hug and Zhang, 2010: p. 10) advise the Western states to take cognizance of the fact that the time window when they have a comparative advantage in technology is gradually closing, so their leverage over Kazakhstan is progressively waning. This argument, nonetheless, appears questionable at least for two reasons. First, some studies show that though the economies of a number of developing states are growing fast, developed Western states are still likely to have far better GDPs per capita and life standards by 2050 (e.g. PWC, 2015). Second, scholars commonly argue that thanks to democracy, freedoms and liberal values, the West has the environment ensuring its long-term competitive advantage in research, science and innovations (e.g. Cox, 2012).

\section{Endnotes}

${ }^{1}$ The Enhanced Partnership and Cooperation Agreement (EPCA), concluded in December 2015 to replace the 1999 EU-Kazakhstani Partnership and Cooperation Agreement (PCA).

${ }^{2}$ For instance, as McGlinchey (2013) shows, despite the violent breaking of a workers' strike in the city of Zhanaozen in 2011 (the so-called the Zhanaozen massacre), the Nazarbayev regime generally treated with understanding and recognised the legitimacy of protesters' demands in similar occurrences henceforth. This compares Uzbekistan's autocratic leader Islam Karimov who used the 2005 Andijan protests to consolidate his regime, presenting the demonstrators as Islamic radicals and himself as the sole force capable of protecting the country from them.

${ }^{3}$ Those who regard Nazarbayev's participation in the EAEU to be political may dismiss the long-term-economic-benefits argument as cheap talk, citing the organisation's poor record as well as the fact that although Russia and Kazakhstan share their longest borders with one another, Moscow is Astana's only third largest trade partner. Yet, orientation toward long-term results seems to be a common line in Nazarbayev's presidential style, largely manifesting itself in his annual presidential addresses (for details, see Ambrosio and Lange, 2014), Eurasianist ideology (for details, see Mostafa, 2013) as well as the Kazakhstan-2030 and Kazakhstan-2050 developmental strategies. Moreover, the inclination to long-dated goals is also evident in his foreign policy moves. For instance, such is the case with Kazakhstan's recent accession to WTO, of which Nazarbayev had been an active proponent, though it will hardly give his country any short-term gains given that, as Anceschi (2014: p. 5) notes, "[there are] limited benefits that full WTO membership could bring to a recourse-based economy".

${ }^{4}$ There are also domestic goals for the use of this ideology (for details, see Mostafa, 2013: p. 166). 
${ }^{5}$ For the same reason, wrong seem those authors who argue that Kazakhstan would love to enhance its cooperation with the West, though its geographical location limits such aspirations: Ambrosio \& Lange (2014: p. 549), for instance, state that "the full extent to which this foreign policy is truly multi-vectored is limited by Kazakhstan's geographical realities: its immediate neighbourhood is obviously more consequential than those farther afield, which means that true multi-vectorness is restricted by the precedence that relations with Russia and China take over relations with the United States and Europe".

${ }^{6}$ Jarosiewicz (2016: p. 30) views it as a paradox that Kazakhstan turns to the West for advise on development, though it is commonly considered as one of the most committed friends of Russia.

${ }^{7}$ Western commentators, however, tend to heavily criticise this cooperation (e.g. Mendick, 2016), in particular, because Blair was noted for providing Nazarbayev with PR recommendations on how to cope with the reputation consequences of the Zhanaozen massacre.

${ }^{8}$ According to Dzhuraev (2012: p. 2), autocracies frequently point to the arguably important role they play in world debates and international organisations so as to gain domestic legitimacy. Moreover, as argued by Schatz (2006), resorts to foreign policy as a strategy of domestic legitimation are especially common where and when authoritarian regimes have a shortage of internal sources of legitimacy. Albeit this is not exactly Kazakhstan's case in general, given that Nazarbayev can always point to the relative success of his economic reforms, one can still argue international sources of legitimacy came in handy for him, for instance, during the 2014-2015 dramatic depreciation of the Tenge, Kazakhstan's national currency. Interestingly, in his comparative study on the foreign policies of Kazakhstan and Uzbekistan on the one hand and Kyrgyzstan on the other, McGlinchey (2012) came to the conclusion that sometimes autocratic leaders may be more supportive of the West than democratic ones, which happens exactly because of the formers' need for an additional source of gaining domestic legitimacy.

${ }^{9}$ Though that particular proposition has never been implemented, it was consistent with the overall spirit of Nazarbayev's rule, which provides for taking highly revolutionary, sometimes overtly radical, steps. Among such, one can remember the 1998 transfer of the national capital to Astana, the 2017 decree on the Kazakh language's transition to a Latin-based script, the call to gradually establish a so-called "trinity of languages" which will transit to English all national education starting from the penultimate year of high school (Nazarbayev, 2017) as well as the 1993 initiation of the Bolashak program providing talented Kazakhstanis an opportunity to study in the leading international-predominantly Western-universities with a state scholarship if they later work in Kazakhstan for at least five years.

${ }^{10}$ Naturally, my use of the conjunction "and" in this sentence should not be regarded as if the two purposes are very separate from each other, for, as theory suggests, nation branding may be helpful both for strengthening the country's economy and, indirectly, consolidating the ruling regime. As one description of potential gains from nation branding argues (de Chernatony, 2008: p. 17), "in addition to the key goals of attracting tourists, stimulating inward investment and boosting exports, nation branding can also increase currency stability; help restore international credibility and investor confidence; reverse international ratings downgrades; increase international political 
influence; stimulate stronger international partnerships and enhance nation building (by nourishing confidence, pride, harmony, ambition, national resolve)".

${ }^{11}$ Incidentally, the academic community seems to replicate a similar approach: in the author's observation, Western researchers, even while taking account of its authoritarian regime, still portray Kazakhstan in a somewhat positive light, which compares with, for instance, Russia that is usually depicted negatively.

${ }^{12}$ Interestingly, not only Western powers view Kazakhstan as a potentially good mediator: in late 2016, for instance, Russia, Turkey and Iran backed for holding peace talks between the Syrian government and opposition in Astana, seven rounds of which the city hosted in 2017 (see Mühlberger, 2017 for details).

${ }^{13}$ Notably, the fact that anti-Westernism and strong unacceptance of the West's criticism is present in Putin's and absent in Nazarbayev's foreign policies across various instances correlates well with their approaches to domestic protests: while Putin is known for never conceding at any price, Nazarbayev is more attentive to public opinion (Jarosiewicz, 2016: p. 29). This may refer to the psychological complexes, such as narcissism and bullyism, intrinsic in Putin's personality (for details, see Forsberg and Pursiainen, 2017: pp. 14-19) and apparently absent in Nazarbayev's.

${ }^{14}$ Remarkably, to understand EU policy toward Kazakhstan, considering the bloc's approach to Central Asia as a whole seems important, because, even though the $2007 \mathrm{EU}$ Strategy for Central Asia underlines the significance of treating each Central Asian state individually (Council of the EU, 2007: p. 6) and moreover, as I stated above, the EU is argued to conditionally discriminate between the region's "potentially promising pupils" and "problematic cases" (Kavalski and Cho, 2017: p. 6), allocating 70\% of its aid through bilateral instead of region-wide programs (ibid: p. 9), the discourse analysis of the media shows that European officials tend to relate EU ties with Kazakhstan to the bloc's overall policy toward the region. As Ospanova et al. (2017: p. 79) put it, "[a]lthough Europeans recognize closer relations with Kazakhstan compared to its neighbors, they do not treat Astana as a privileged partner in the region", noting that the Kazakhstani elites, by contrast, willingly emphasise every accomplishment of their country in its ties with the EU.

${ }^{15}$ This does not mean EU members are equally interested in and contributing to collaboration with Central Asia: pointing to the fact that the 2007 Strategy was primarily authored by Germany and adopted during its presidency, scholars extensively contend the document somewhat portrays German interests in the region as common EU ones (Laumullin, 2011: p. 31; Voloshin, 2014: p. 43). Moreover, Kavalski and Cho (2017: p. 9) note Germany's successors have arguably been less prone to continuing Germany's active stance on Central Asia.

${ }^{16}$ Again, this is not to say that all EU members share the same perception of the bloc's democracy promotion priorities: Bossuyt (2016), for instance, shows that Poland's relative passivity in Central Asia is balanced by its active engagement in democracy promotion in the Eastern Partnership states.

${ }^{17}$ Interestingly, the EU, in turn, tends to play the role of a scapegoat for its member countries which refrain from criticising Kazakhstan, trying to make Brussels do this "dirty job" instead (Bossuyt and Kubicek 2015: p. 184).

${ }^{18}$ Remarkably, in view of the bloc's desire to lessen Russia's energy influence, the 2007 Strategy considers the development of infrastructure in the North-South direction and pipeline diversification as European security issues (Council of the EU, 2007). 
${ }^{19}$ Again, this point should not be interpreted as though all EU members and institutions share the same attitude. The European Parliament, for instance, is traditionally stronger committed to democracy and human rights, criticising Astana more than the other EU bodies (Tsertsvadze and Axyonova, 2013: p. 3; Kembayev, 2016: pp. 189-190). A similar situation is in OSCE, where the US and the UK, driven by political and ideological rather than economic considerations, used to strongly oppose Kazakhstan's 2010 chairmanship, while the position of Germany and Germany-led EU members was far more moderate (Fülscher, 2007: p. 2).

${ }^{20}$ Notably, my argument is that Astana pursues a pragmatic policy toward the EU for real, which, in fact, may be different from merely talking about pragmatism. Interestingly, in Kazakhstan's case, pragmatism-however ironical it may seem-seems to have become part of the country's foreign policy ideology: the notion of pragmatism appears to have penetrated into the country's official discourse so profoundly that few, if any, official speeches and documents fail to mention it. It is illustrative that Kazakhstan's Foreign Policy Concept (Embassy of Kazakhstan in Armenia, 2017) makes six mentions of the word "pragmatism" and its derivatives, while Russia's Concept (MFA of Russia, 2016), which is 2.5 times longer, mentions this word only once.

${ }^{21}$ This makes him different from other Central Asian leaders, in particular, Kyrgyz President Almazbek Atambayev who is notorious for regretting about the Soviet Union's collapse (Regnum, 2012).

${ }^{22}$ Such is, for instance, the case with Georgia (Kakachia and Minesashvili, 2015) and the Baltics (Berg and Ehin, 2009).

${ }^{23}$ On this point, an analogy can be drawn with Uzbekistan: after the death of its longstanding dictator Islam Karimov in September 2016, commentators commonly argued the victory of former Prime Minister Shavkat Mirziyoyev would imply the regime's toughening. However, contrary to such expectations, Mirziyoyev proved himself to be rather a reformist in the first year of his presidency, albeit the sincerity of his moves remains open to interpretation (Abdurasulov, 2017).

${ }^{24}$ Especially implausible seem the accounts arguing human rights should be at the core of the bloc's attention: Boostra \& Tsertsvadze (2016: 7), for example, suggest that "[a]lthough the EU has little influence in Central Asia, adherence to democratic principles should be the centrepiece of engagement".

${ }^{25}$ Yet, some of these accounts seem to push this argument too far, idealising azarbayev's intentions and neglecting the fact that no matter how much Nazarbayev cares about Kazakhstan's image and modernisation, staying in power is ultimately more important for him. A good instance of such an account is Tsertsvadze and Axyonova's suggestion that "[a] clear EU stance on Kazakhstan's democratic and human rights commitments would be mutually beneficial: political stability rooted in democratic principles would strengthen the country's profile on the global stage, while the EU would gain a more reliable partner" (2013: 2).

\section{Acknowledgements}

I would like to thank my supervisor Prof. Alessandro Colombo for his helpful remarks on an earlier draft of this paper.

Funding

Not relevant.

Availability of data and materials

Not relevant. 
Authors' contributions

All authors read and approved the final manuscript.

\section{Authors' information}

Artem Patalakh is finishing a PhD in Political Studies at the Graduate School of Social and Political Sciences of the University of Milan, Italy. He earned Bachelor's and Master's degrees in Regional Studies from Moscow State Institute of International Relations. His recent publications concentrate on soft power, human rights promotion, geopolitics of the post-Soviet space and the foreign policies of the EU and Russia.

\section{Competing interests}

I declare that I have no competing interests.

\section{Publisher's Note}

Springer Nature remains neutral with regard to jurisdictional claims in published maps and institutional affiliations.

Received: 18 November 2017 Accepted: 9 February 2018

Published online: 13 February 2018

\section{References}

Abdurasulov, Abdujalil. 2017. Zachem uzbekskomu prezidentu liberal'nye reformy? BBC, 14 September. http://www.bbc com/russian/features-41269455. Accessed 3 Nov 2017.

Akkazieva, and Gulnura. 2012. The EU's current policy in Central Asia: Trends of development. Vestnik MGIMO-University 3 (24): $220-226$.

Ambrosio, Thomas, and William Lange. 2014. Mapping Kazakhstan's geopolitical code: An analysis of Nazarbayev's presidential addresses, 1997-2014. Eurasian Geography and Economics 55 (5): 537-559.

Anceschi, Luca. 2014. The tyranny of pragmatism: EU-Kazakhstani relations. Europe-Asia Studies 66 (1): 1-24.

Batsaikhan, Uuriintuya, and Marek Dabrowski. 2017. Central Asia at 25. Bruegel Policy Contribution 13.

BBC News. 2014. Kazakhstan: President suggests renaming the country, 7 February. http://www.bbc.com/news/blogsnews-from-elsewhere-26082740. Accessed 17 Nov 2017.

Berg, Eiki, and Piret Ehin, eds. 2009. Identity and Foreign Policy: Baltic-Russian Relations and European Integration. Farham, surrey. Ashgate.

Bolekbaeva, Dana, and Irina Selivanova. 2015. Osnovnye napravlenija vneshnej politiki Kazahstana (1991-2015 gg.) in Foreign Policy of the New Independent States, ed. Boris Shmelyov, 206-234. Moscow: Institute of Economics of the Russian Academy of Sciences.

Boonstra, Jos, and Tika Tsertsvadze. 2016. Implementation and review of the European Union-Central Asia strategy: Recommendations for EU action. Brussels: European Parliament.

Bossuyt, Fabienne. 2016. Central and eastern European EU member states' involvement in the EU's democracy promotion in Central Asia. In Democratization in EU foreign policy: New member states as drivers of democracy promotion, eds. Benedetta Berti, Kristina Mikulova, and Nicu Popescu, 102-126. New York: Routledge.

Bossuyt, Fabienne, and Paul Kubicek. 2015. Favouring leaders over laggards: Kazakhstan and Kyrgyzstan. In The substance of EU democracy promotion: Concepts and cases, ed. Anne Wetzel and Jan Orbie, 177-192. New York: Palgrave Macmillan.

Collins, Neil, and Kristina Bekenova. 2017. Fuelling the new great game: Kazakhstan, energy policy and the EU. Asia-Europe. Journal 15: 1-20.

Council of the EU. 2007. The EU and Central Asia: Strategy for a new partnership. Brussels: General Secretariat of the Council.

Cox, Michael. 2012. Power shifts, economic change and the decline of the west? International Relations 26 (4): 369-388

Dave, Bhavna. 2007. The EU and Kazakhstan: Balancing economic cooperation and aiding democratic reforms in the central Asian region. CEPS Policy Brief 127.

de Chernatony, Leslie. 2008. Academic perspective: Adapting brand theory to the context of nation branding. In Nation branding: Concepts, issues, practice, ed. Keith Dinnie, 16-22. London: Butterworth-Heinemann.

Diener, Alexander. 2015. Assessing potential Russian irredentism and separatism in Kazakhstan's northern oblasts. Eurasian Geography and Economics 56 (5): 469-492.

Dzhuraev, Shairbek. 2012. Governance challenges in post-soviet Kyrgyzstan: The externalization and Parochialization of political legitimacy. Oslo: Norwegian Institute of International Affairs.

EIU. 2010. Democracy index 2010: Democracy in retreat. London: EIU Limited.

EIU. 2017. Democracy index 2016: Revenge of the "Deplorables". London: EIU Limited.

Embassy of Kazakhstan in Armenia. 2017. Foreign Policy Concept for 2014-2020 Republic of Kazakhstan. http://mfa.gov.kz/ en/erevan/content-view/koncepcia-vnesnej-politiki-rk-na-2014-2020-gg. Accessed 3 Nov 2017.

Engvall, Johan, and Svante Cornell. 2015. Asserting statehood: Kazakhstan's role in international organizations. Washington: Central Asia-Caucasus Institute \& Silk Road Studies Program.

EU External Action. 2017. EU-Kazakhstan Relations, 15 June. https://eeas.europa.eu/headquarters/headquartershomepage_en/4076/EU-Kazakhstan\%20relations. Accessed 3 Nov 2017.

Eurasian Economic Commission. 2017. Vzaimnaja torgovlja tovarami. Statistika Evrazijskogo ekonomicheskogo sojuza. 2016 god. Statisticheskij sbornik. Moscow: Sam Poligrafist.

EurasiaNet. 2015. Kazakhstan: NGO Law Approved Amid Civil Society Resistance, 2 December. http://www.eurasianet. org/node/76366. Accessed 3 Nov 2017.

European Commission. 2007. Central Asia Indicative Program (2007-2010). http://eeas.europa.eu/archives/docs/central asia/rsp/nip_07_10_en.pdf. Accessed 3 Nov 2017. 
European Commission. 2011. Central Asia DCI Indicative Programme (2011-2013). https//eeas.europa.eu/sites/eeas/files/central_ asia_multi-annual_indicative_programme_2011-2013_of_the_eu_development_co-operation_instrument_dci.pdf. Accessed 3 Nov 2017.

European Commission. 2014. Multiannual Indicative Programme Regional Central Asia 2014-2020. https://ec.europa.eu/ europeaid/sites/devco/files/mip-2014-2020-central-asia-regional-20140812-en.pdf. Accessed 3 Nov 2017.

Faizova, Renata. 2011. Kazakhstan between east and west: OSCE Kazakhstan chairmanship in 2010. Vestnik RUDN. International Relations 1: 32-37.

Forsberg, Tuomas, and Christer Pursiainen. 2017. The psychological dimension of Russian foreign policy: Putin and the annexation of Crimea. Global Society. https://doi.org/10.1080/13600826.2016.1274963.

Forum. 2014. Nazarbaev: Pri formirovanii EAES nuzhno ispol'zovat' opyt ES, 29 May. http://for-ua.com/world/2014/05/ 29/124205.html. Accessed 16 Nov 2017.

Freedom House. 2010a. Freedom in the World 2010: Kazakhstan. https://freedomhouse.org/report/freedom-world/2010/ kazakhstan. Accessed 3 Nov 2017.

Freedom House. 2010b. Freedom of the Press 2010: Kazakhstan. https://freedomhouse.org/report/freedom-press/2010/ kazakhstan. Accessed 3 Nov 2017.

Freedom House. 2017a. Freedom in the World 2017: Kazakhstan. https://freedomhouse.org/report/freedom-world/2017/ kazakhstan. Accessed 3 Nov 2017.

Freedom House. 2017b. Freedom of the Press 2017: Kazakhstan. https://freedomhouse.org/report/freedom-press/2017/ kazakhstan. Accessed 3 Nov 2017.

Fülscher, Kimana. 2007. Flawed elections in Kazakhstan: How will the international community react? FRIDE: Comment.

Government of Kazakhstan. 2008. Ob utverzhdenii Plana meroprijatij po realizacii Gosudarstvennoj programmy "Put' v Evropu" na 2009-2011 gody, 4 October. http://egov.kz/cms/en/law/list/P080000916_. Accessed 3 November 2017.

Gubaidullina, Mara. 2001. Prioritety i perspektivy sotrudnichestva Evropejskogo Sojuza i Kazahstana: kriticheskij aspekt. The KazNU Journal. International Relations and International Law Edition 3-4 (53-54): 36-42.

Headley, James. 2015. Challenging the EU's claim to moral authority: Russian talk of "double standards". Asia-Europe Journal 13 (3): 297-307.

Holmquist, Erika. 2015. Kazakhstan after Crimea: "You cannot choose your Neighbours". RUFS Briefing 26.

Hug, Adam. 2009. Kazakhstan at a crossroads: Human rights and democracy. London: The Foreign Policy Centre.

Hug, Adam, and Feng Zhang. 2010. Kazakhstan at a crossroads: Kazakhstan and the world. London: The Foreign Policy Centre.

Idrissov, Erlan. 2011. Kazakhstan makes real progress toward democracy. The Hill (19 April) http://thehill.com/blogs/ congress-blog/foreign-policy/156739-kazakhstan-makes-real-progress-toward-democracy. Accessed 3 Nov 2017.

Jarosiewicz, Aleksandra. 2016. Perestroika - The Nazarbayev way: Crisis and reforms in Kazakhstan. Warsaw: OSW.

Kakachia, Kornely, and Salome Minesashvili. 2015. Identity politics: Explaining Georgian foreign policy behavior. Journal of Eurasian Studies 6 (2): 171-180.

Kavalski, Emilian, and Young Chul Cho. 2017. The European Union in central Eurasia: Still Searching for Strategy. AsiaEurope Journal. https://doi.org/10.1007/s10308-017-0484-3.

Kembayev, Zhenis. 2016. Partnership between the European Union and the Republic of Kazakhstan: Problems and perspectives. European Foreign Affairs Review 2: 185-204.

Khan, Haroon. 2014. Pragmatic liberalism and President Obama: An analysis of U.S. foreign policy toward Bangladesh. SAGE Open. https://doi.org/10.1177/2158244014541130

Khatib, Lina. 2013. Qatar's foreign policy: The limits of pragmatism. International Affairs 89 (2): 417-431.

Koch, Natalie. 2013. Kazakhstan's changing geopolitics: The resource economy and popular attitudes about China's growing regional influence. Eurasian Geography and Economics 54 (1): 110-133.

Konopelko, Agnieszka. 2017. Eurasian economic union: A challenge for EU policy towards Kazakhstan. Asia-Europe Journal. https://doi.org/10.1007/s10308-017-0480-7.

Kuchins, Andrew, Jeffrey Mankoff, Aitolkyn Kourmanova, and Oliver Backes. 2015. Central Asia in a reconnecting Eurasia: Kazakhstan's evolving foreign economic and security interests. Washington: CSIS.

Kurmanguzhin, Rustem. 2015. On partnership and cooperation agreement between Kazakhstan and European Union. Russia and New States of Eurasia 4: 33-43.

Kurmanguzhin, Rustem. 2016. Kazakhstan and the EU: From cooperation strategy to the new agreement on the advanced partnership. Comparative Politics Russia 1 (22): 106-115.

Kuzmina, Elena. 2014. Economic positions of the European Union in Central Asia in the context of EU crisis. Belarusian Economic Journal 3: 4-14.

Makili-Aliyev, Kamal. 2013. Azerbaijan's foreign policy: Between east and west. IAl Working Papers 13/05.

Malysheva, Dina. 2010. Central'naja Azija i Evropejskij Sojuz. Russia and New States of Eurasia 2 (7): 24-34.

McGlinchey, Eric. 2012. Foreign policy and aging central Asian autocrats. Demokratizatsiya 20 (3): 262-267.

McGlinchey, Eric. 2013. States of protest in Central Asia. PONARS Eurasia Policy Memo 299.

Meden, Natalya. 2012. Strategija ES v Central'noj Azii: Uroki i perspektivy. Russia and New States of Eurasia 4 (17): 52-60.

Mendick, Robert. 2016. Tony Blair's $£ 5 \mathrm{~m}$ deal to advise Kazakh dictator. The Telegraph, 23 April. http://www.telegraph. co.uk/news/2016/04/23/tony-blairs-5m-deal-to-advise-kazakh-dictator/. Accessed 3 Nov 2017.

MFA of Russia. 2016. Foreign policy concept of the Russian Federation, 1 December. http://www.mid.ru/en/foreign_ policy/official_documents/-/asset_publisher/CptlCkB6BZ29/content/id/2542248. Accessed 3 Nov 2017.

Miller, Manjari, and Kate De Estrada. 2017. Pragmatism in Indian foreign policy: How ideas constrain Modi. International Affairs 93 (1): 27-49.

Mostafa, Golam. 2013. The concept of 'Eurasia': Kazakhstan's Eurasian policy and its implications. Journal of Eurasian Studies 4: 160-170.

Mühlberger, Wolfgang. 2017. Astana's Syria conference: Musical chairs on Moscow's terms. FllA Comment 4

Nazarbayev, Nursultan. 1999. Poslanie Prezidenta Respubliki Kazahstan N.A. Nazarbaeva narodu Kazahstana, 16 September. http://www.akorda.kz/ru/addresses/addresses_of_president/poslanie-prezidenta-respubliki-kazakhstan-na-nazarbaeva-narodu-kazakhstana-sentyabr-1999-g_1342416713. Accessed 3 Nov 2017. 
Nazarbayev, Nursultan. 2017. The president of Kazakhstan Nursultan Nazarbayev's address to the nation of Kazakhstan, 31 January. http://www.akorda.kz/en/addresses/addresses_of_president/the-president-of-kazakhstan-nursultannazarbayevs-address-to-the-nation-of-kazakhstan-january-31-2017. Accessed 3 Nov 2017.

Nurgaliyeva, Lyailya. 2016. Kazakhstan's economic soft balancing policy vis-à-vis Russia: From the Eurasian union to the economic cooperation with Turkey. Journal of Eurasian Studies 7: 92-105.

Nurmakov, Adilzhan. 2016. Kazakhstan and the global industry of mega events: A case of autocratic management. In Mega events in post- soviet Eurasia: Shifting borderlines of inclusion and exclusion, ed. Andrey Makarychev and Alexandra Yatsyk, 99-130. New York: Palgrave Macmillan.

Öge, Kerem. 2017. Elite preferences and transparency promotion in Kazakhstan. Communist and Post-Communist Studies 50: $135-143$.

Ospanova, Bakyt, Houman Sadri, and Raushan Yelmurzayeva. 2017. Assessing EU perception in Kazakhstan's mass media. Journal of Eurasian Studies 8: 72-82.

Patalakh, Artem. 2017. Economic or geopolitical? Explaining the motives and expectations of the Eurasian economic Union's member states. Fudan Journal of the Humanities and Social Sciences. https://doi.org/10.1007/s40647-0170191-x.

Patalakh, Artem. 2018. Soft Power Revisited: What Attraction Is in International Relations. PhD thesis, University of Milan.

President of Kazakhstan. 2008. O Gosudarstvennoj programme "Put' v Evropu" na 2009-2011 gody, 29 August. https:// tengrinews.kz/zakon/prezident_respubliki_kazahstan/hozyaystvennaya_deyatelnost/id-U080000653_/\#z19. Accessed 3 Nov 2017

PWC. 2015. The World in 2050: Will the Shift in Global Economic Power Continue? Available at: https://www.pwc.com/gx/ en/issues/the-economy/assets/world-in-2050-february-2015.pdf. Accessed 3 Nov 2017.

Radio Azattyq. 2016. ES prizyvaet Nazarbaeva sobljudat' prava cheloveka, 30 March. https://rus.azattyq.org/a/27644105. html. Accessed 3 Nov 017

Regnum. 2012. Prezident Kirgizii: My vsegda budem zhalet' o tom, chto razvalilsja Sovetskij Sojuz, 22 June. https:// regnum.ru/news/polit/1544392.html. Accessed 3 Nov 2017.

Rettman, Andrew. 2011. Lukashenko hurls vulgarities at Barroso. EUObserver (27 April) https://euobserver.com/foreign/ 32233. Accessed 3 Nov 2017

RFE/RL. 2015. Nazarbaev calls US, EU sanctions on Russia "barbaric", 11 February. https://www.rferl.org/a/kazakhstanrussia-sanctions-us-eu-nazarbaev/26841705.html. Accessed 3 Nov 2017.

Roberts, Sean. 2015. The Ukraine conflict and the future of Kazakhstan's multi-vector foreign policy. PONARS Eurasia Policy Memo 388.

Roslycky, Lada. 2011. Russia's smart power in Crimea: Sowing the seeds of trust. Southeast European and Black Sea Studies 11 (3): 299-316.

Savchenko, Igor. 2015. Kazakhstan Rejects Statements of the UN, EU and OSCE on Violations of Human Rights. Open Dialog Foundation, 30 November. http://en.odfoundation.eu/a/7073,kazakhstan-rejects-statements-of-the-un-euand-osce-on-violations-of-human-rights. Accessed 3 Nov 2017.

Sayfullayev, Durbek. 2016. Uzbekistan's diplomacy in the modern international relations system. Journal of Public Affairs. https://doi.org/10.1002/pa.1611.

Schatz, Edward. 2006. Access by accident: Legitimacy claims and democracy promotion in authoritarian Central Asia. International Political Science Review 27 (3): 263-284.

Shaymergenov, Timur, and Marat Biekenov. 2010. Kazakhstan and NATO: Evaluation of cooperation prospects. Central Asia and the Caucasus 11 (1): 35-51.

Sivokin, Pavel. 2011. Manevry Nursultana Nazarbayeva. Glavred, 5 April. Available at: http://glavred.info/archive/2011/04/ 05/132250-8.html.

Svarin, David. 2016. The construction of 'geopolitical spaces' in Russian foreign policy discourse before and after the Ukraine crisis. Journal of Eurasian Studies 7 (2): 129-140

Tengri News. 2014. Nazarbaev poruchil racional'no ispol'zovat' yydelennye na obrazovanie sredstva, 7 April. https://tengrinews. kz/kazakhstan_news/nazarbaev-poruchil-ratsionalno-ispolzovat-vyidelennyie-253213/. Accessed 16 Nov 2017.

Tsertsvadze, Tika, and Vera Axyonova. 2013. Trading values with Kazakhstan. EUCAM Policy Brief 32.

Vanderhill, Rachel. 2017. Active resistance to democratic diffusion. Communist and Post-Communist Studies 50: 41-51.

Voloshin, Georgiy. 2014. The European Union's normative power in Central Asia: Promoting values and defending interests. New York: Palgrave Macmillan.

Vremya. 2017. Kazahstan izuchaet opyt evropejskih stran dlja vnedrenija luchshej sudebnoj praktiki - Nazarbaev, 21 August. http://www.time.kz/news/politics/2017/08/21/kazahstan-izuchaet-opit-evropejskih-stran-dlja-vnedrenijaluchshej-sudebnoj-praktiki-nazarbaev. Accessed 16 Nov 2017. 